\title{
REKONTRUKSI SENI TRADISI BUMBUNG GEBYOG UNTUK MENUNJANG DESA WISATA PINGE KECAMATAN MARGA KABUPATEN TABANAN
}

\author{
I.M. Mega ${ }^{1}$, N.L.R. Purnawan ${ }^{2}$, dan N.W. Suartini ${ }^{3}$
}

\begin{abstract}
ABSTRAK
Kegiatan pengabdian kepada masyarakat ini bertujuan rekontruksi tari tradisi bumbung gebyog menjadi seni pertunjukan bagi wisatawan di Desa wisata Pinge, Kecamatan Marga, Kabupaten Tabanan. Metode yang diterapkan dalam pemberdayaan masyarakat ini adalah sebagai berikut: (1) Kordinasi dan komunikasi secara partisipasif dengan desa adat/pengola desa wisata Pinge untuk merumuskan program mulai dari perencanaan, operasional dan evaluasi; (2) mengumpulkan informasi tentang tarian bumbung gebyog dari pihak-pihak yang terlibat dalam kesenian bumbung gebyog dimasa lalu; (3) kontruksi gerakan tari dan koreografi pertunjukkan bumbung gebyog; (4) Pendampingan yaitu pertemuan secara berkala dan berkelanjutan antara pendamping dengan masyarakat sasaran hingga ipteks yang dialihkan dapat dilaksanakan secara mandiri oleh masyarakat. Hasil yang diperoleh menunjukkan bahwa kegiatan rekontruksi tarian bumbung gebyog sudah bejalan dengan ditandai oleh penguasaan penari dan pemain gambelan yang cukup baik. Setelah 9 (sebilan) kali pertemuan seluruh penari sudah mampu mempraktekan gerakan tari secara mandiri. Begitu pula dengan ketrampilan personel penabuh, seluruh penabuh telah mampu memainkan nada tari yang dilatihkan sesuai dengan instrumen masing-masing. Tarian bumbumbung gebyog hasil rekontruksi sudah dipentaskan pada acara pencanganan Desa Wisata yang dihadiri oleh menteri Badan Usaha Milik Negara (BUMN).
\end{abstract}

Kata Kunci : rekonstruksi, tari tradissional, desa wisata.

\begin{abstract}
Community service activities aims to reproduce the traditional dance "Bumbung Gebyog " into a peformance for tourists in the village tourism Pinge, District of Marga, Kabupaten Tabanan. The method applied in community service are as follows: (1) coordination and participatory communication with indigenous villages / manager of a tourist village Pinge to formulate a program from the planning, operational and evaluation; (2) gather information about the dance "bumbung gebyog" of the parties involved in the arts in the past gebyog tube; (3) construction of dance movements and choreography performances gebyog tube; (4) Assistance is meeting regularly and sustainably among companion with target communities to science and technology transferred can be carried out independently by the community. The results obtained showed that the reconstruction activities bumbung dance gebyog already shooting went well marked by the mastery of the dancers and gamelan players were pretty good. After the 9 (nine) meetings throughout the dancers have been able to practice dance moves independently. Similarly, the skills gambelan players, all musicians have been able to play a dance tone drilled in accordance with their respective instruments. Dance tube gebyog result of reconstruction has been staged at the Tourism Village louncing which was attended by Minister of State Owned Enterprises (SOEs).
\end{abstract}

Keywords: recontruction, trdisional dancing, tourism village

${ }^{1}$ Staf Pengajar Fakultas Pertanian Universitas Udayana, mega_made@yahoo.com

${ }^{2}$ Staf Pengajar FISIP Universitas Udayana

${ }^{3}$ Staf Pengajar ISI Denpasar 


\section{PENDAHULUAN}

Desa wisata Pinge terletak di Desa Pekraman Pinge, Desa Baru, Kecamatan Marga kabupaten Tabanan, berada diketinggian 500 meter diatas permukaan laut (BPS Kabupaten Tabanan, 2016). Desa tersebut berjarak $17 \mathrm{~km}$ arah utara kota Tabanan (Anon., 2015). Desa Wisata Pinge merupakan desa tua yang menjadi salah satu objek wisata yang ada di Bali. Desa ini memiliki keunikan tersendiri yaitu bentuk rumah penduduk yang berarsitektur tradisional sejajar dan tertata rapi. Desa Wisata ini memiliki panorama alam yang sangat indah dengan hamparan persawahan yang hijau membentang. Wisatawan yang datang kesini bisa melihat secara langsung kegiatan pertanian antara lain: para petani membajak sawah, menyiapkan bibit, menanam padi, menuai dan memasukan padi ke lumbung. Selain potensi alam dan bentuk bangunan tradisional Bali, di Desa wisata Pinge juga terdapat seni tradisi yang sangat unik yang disebut bumbung gebyog. Menurut Surya (1986, dalam Ariawan ,2014), mengatakan Gambelan bumbung gebyog merupakan kesenian khas daerah bali bagian barat yaitu daerah tingkat II Jembrana, istilah bumbung gebyog berasal dua kata yaitu dari kata bumbung dan gebyog.

Bumbung adalah bamboo yang terdiri dari satu atau beberapa ruas yang pada ujungnya dipotong sedemikian rupa sehingga berlubang dan pada pangkalnya dibiarkan tertutup. Sedangkan gebyog adalah suara yang ditimbulkan oleh instrument bumbung. Dalam rangka menunjang Desa wisata Pinge, ada keinginan masyarakat untuk mengemas tarian tradisi ini sebagai seni pertunjukkan bagi wisatawan. Namun demikian, masyarakat sudah tidak mampu lagi mempertunjukkan kesenian tersebut karena sudah lama tidak dipertunjukkan lagi. Para penari dan pemain gambelan pengiring rata-rata sudah berusia usur. Berkaitan dengan hal tersebut, tim Universitas Udayana dan ISI Denpasar melalui program IbW melakukan rekontruksi atau menghidupkan kembali kesenian tersebut untuk dikembangkan menjadi seni pertunjukkan bagi wisatawan.

\section{METODE PELAKSANAAN}

Metode yang diterapkan dalam pemberdayaan masyarakat ini adalah sebagai berikut: (1) Koordinasi dan komunikasi secara partisipasif dengan desa adat/pengola desa wisata Pinge untuk merumuskan program mulai dari perencanaan, operasional dan evaluasi; (2) mengumpulkan informasi tentang tarian bumbung gebyog dari pihak-pihak yang terlibat dalam kesenian bumbung gebyog dimasa lalu; (3) kontruksi gerakan tari dan koreografi pertunjukkan bumbung gebyog; (4) Pendampingan yaitu pertemuan secara berkala dan berkelanjutan antara pendamping dengan masyarakat sasaran hingga ipteks yang dialihkan dapat dilaksanakan secara mandiri oleh masyarakat.

\section{HASIL DAN PEMBAHASAN}

Kegiatan rekontruksi dimulai dengan mengumpulkan informasi mengenai tari gebyog, mulai dari sejarahnya, momen pertunjukannya, jumlah penari, instrumen tari, koreografi dan lain-lainnya. Melalui informasi tersebut selanjutnya dirancang tarian yang sejauh mungkin mendekati dengan gerakan, nada instrumen dan langgam tarian bumbung gebyog.

Tarian bumbung gebyog ditarikan oleh penari perempuan (gadis) berjumlah 5 orang. Tarian ini diiringi oleh instrumen yang terbuat dari bambu. Seperti instrumen tari Bali pada umumnya pada tarian bumbung gebyog ini juga terdiri dari pemandu nada, kempul, seruling, dan gong. Hanya saja seluruh intrumennya terbuat dari bambu (Gambar 1).

\section{4 | BULETIN UDAYANA MENGABDI}


Hasil yang diperoleh menunjukkan bahwa kegiatan rekontruksi tarian bumbung gebyog sudah berhasil menciptakan tarian bumbung gebyog yang dijadikan pertunjukan bagi wisatawan. Setelah 9 (sebilan) kali pertemuan seluruh penari sudah mampu mempraktekan gerakan tari secara mandiri. Begitu pula dengan ketrampilan personel penabuh, seluruh penabuh telah mampu memainkan nada tari yang dilatihkan sesuai dengan instrumen masing-masing. Tarian bumbung gebyog hasil rekontruksi sudah dipentaskan pada acara pencanganan Desa Wisata yang dihadiri oleh Menteri Badan Usaha Milik Negara (BUMN) tanggal 11 November 2016 (Gambar 2).

Masyarakat memberikan respon yang sangat positif terhadap kegiatan pengabdian ini ditandai oleh tingginya partisipasi penari dan penabuh yang terlibat. Pengabdian masyarakat berbasis ilmu pengetahuan dan teknologi sangat diminati oleh masyarakat karena sesuai dengan kebutuhan dan potensi masyarakat.

\section{KESIMPULAN DAN SARAN}

Berdasarkan hasil kegiatan pengabdian kepada masyarakat rekontruksi seni tradisi bumbung gebyog dalam menunjang Desa Wisata di Desa Pekraman Pinge Kecamatan marga kabupaten Pupuan dapat disimpulkan sebagai berikut:

(1) Hasil yang diperoleh menunjukkan bahwa kegiatan rekontruksi tarian bumbung gebyog sudah bejalan dengan ditandai oleh penguasaan penari dan pemain gambelan yang cukup baik.

(2) Seluruh penari sudah mampu mempraktekan gerakan tari secara mandiri, begitu pula dengan ketrampilan personel penabuh telah mampu memainkan nada tari yang dilatihkan sesuai dengan instrument masing-masing.

(3) Masyarakat memberikan respon yang positif terhadap kegiatan pengabdian masyarakat yang dilakukan karena sesuai dengan potensi dan kebutuhan masyarakat.

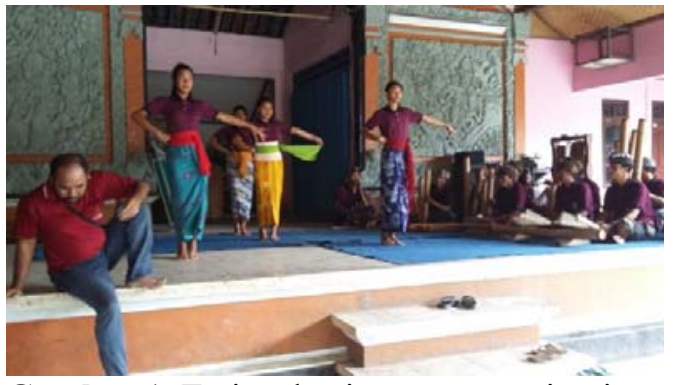

Gambar 1. Tarian dan instrumen seni tari Bumbung Gebyog

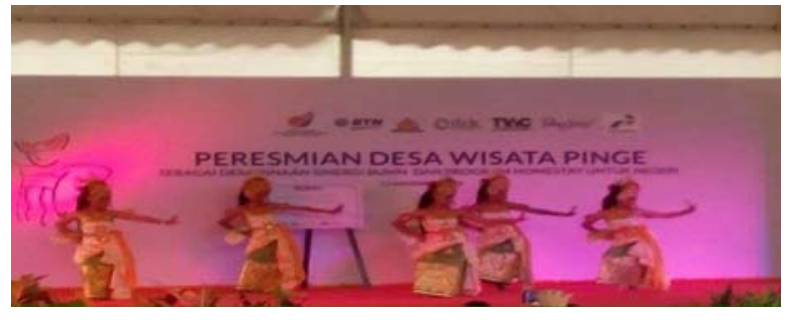

Gambar 2. Hasil rekontruksi seni tari bumbung gebyog

\section{UCAPAN TERIMAKASIH}

Penulis menyampaikan terima kasih yang sebesar-besarnya kepada Direktorat Riset dan pengabdian Masyarakat Kemenristek Dikti atas dana yang diberikan, Ketua Lembaga Pengabdian kepada Masyarakat Universitas Udayana serta masyarakat Desa Wisata Pinge yang telah membantu kelancaran kegiatan ini.

\section{DAFTAR PUSTAKA}

Anonimus. 2015. Monografi Desa Baru, Kecamatan Marga kabupaten Tabanan.

Ariawan, W. 2014. Bumbung Gebyog. Dikutip dari Buku Gambelan Bumbung Gebyog Di Desa Dangintukadaya Negara, (Karya: I Made Surya, 1986). http://blog.isi-dps.ac.id/wayanariawan/tugasmultimedia-artikel-gambelan-bumbung-gebyog.

BPS Kabupaten Tabanan. 2016. Tabanan dalam Angka 2015. Badan Pusat Statistik. 